\title{
THE USE OF DIGITAL TECHNOLOGIES IN SWEDISH TEACHER EDUCATION: EXPERIENCES BY MIGRANT TEACHERS
}

\author{
Annika Käck \\ Stockholm University, Sweden
}

\begin{abstract}
Migrant teachers who wish to complement their studies to become eligible to teach in Swedish schools are a growing number of teacher students in Swedish teacher education. Since Swedish society is highly digitised, it is of interest to investigate how migrant teachers, attending four Swedish teacher education programmes, view teaching and learning, and moreover, how they estimate and experience the use of digital technologies. The results are discussed in relation to Illeris' redefined transformative learning theory. A convergent mixed methods research design, with a survey $(N=228)$, focus groups $(N=5)$, individual reflective texts $\mathrm{s}(N=30)$, and individual interviews $(N=9)$, was applied. The participants had studied teacher education programmes in 57 countries/regions. The results highlight that some of the learning, when digital technologies were used (concerning values and identity, self-directed learning, and communication), reached the core identity and personality layer, and required learning as change - transformative learning. Migrant teachers expressed that the transformative learning experience took up to a year to accommodate.
\end{abstract}

Keywords: Teacher education; Migrant teachers; Digital technologies; Transformative learning.

\section{Background}

\section{The digitalisation of Swedish society and education}

Two important movements in Swedish society are digitalisation and migration. This study will address migrant teachers who have come to a digitised society where they attend Swedish teacher education. Their view of teaching and learning, as well as their experience with the use of digital technologies in Swedish teacher education, are of interest in relation to Illeris' (2014c) redefined transformative learning.

According to the Organisation for Economic Co-operation and Development (OECD, 2018), Sweden is among the top ten countries when it comes to society's digital transformation. Furthermore, the digital divide in Sweden is narrower than most other countries in the OECD, and the use of digital technologies by individuals is significant. According to Davidsson 
and Thoresson (2017), Swedish people use the internet privately and in school extensively. According to the governmental Swedish National Digital Strategy and reports connected to it (Ministry of Enterprise and Innovation, 2011; Digitalisation Commission, 2014), digital competence includes the ability to keep up with digital technologies to obtain and retain employment. In addition, The National Digitalisation Strategy for the School System (Digitalisation Commission, 2017), states that the modernisation of Sweden starts in school, developing digital competence (having the knowledge and ability to find, analyse, critically reflect, create, and use digital technologies). Digital competence is also detailed in the national curricula (The National Agency for Education. Lgy 11, 2017; Lgr 11, 2017; Lpfö 98, 2016).

\section{The digitalisation of Swedish teacher education}

The demands of an information society are a push factor for a digitised teacher education. Bautista and Ortega-Ruiz (2015) discuss the importance of teachers' professional development in an era of globalisation, educating for the 21st century with self-directed, creative, and critical learners who are competent emotionally, socially, and technologically. Digital competence is discussed in Swedish higher education in the ordinance, "Högskoleförordningen 2014:1096, Annex 2" [The Higher Education Ordinance 2014:1096, Appendix 2] (Ministry of Education and Research, 2014): A future teacher must show digital competence and use it critically in teaching and learning as well as consider the role of the digital environment in the pedagogical occupation. Migrant teachers are expected to meet these requirements when they work in the Swedish school system.

However, teacher education in Sweden has been subject to criticism for not providing teachers-to-be with sufficient training in the pedagogical use of digital technologies, and the municipalities in Sweden complain about newly educated teachers' (Swedish teacher students in general) lack of digital competence. It is argued that teacher education must be in sync with society's development (Digitalisation Commission, 2014, p. 166 and 206). Enochsson (2010) investigated how Swedish teacher students in general at twenty-one teacher education programmes were prepared for future teaching with digital technologies. The integration of pedagogical digital use was missing, and the most common way to use technology was writing reports and communicating. In a more recent study (Demoskop, 2016), 1346 Swedish teacher students (in general) were interviewed about digitalisation in teacher education. Almost 50\% considered themselves insufficiently prepared, in their teacher education programmes, to be able to teach with digital technologies, even though 75\% considered themselves highly digitally competent. There were distinct requests to 
enhance digitalisation, with associations to virtual classrooms, web-based examinations and lectures, and digital technologies that boost student learning.

\section{Migrant teachers in Swedish teacher education}

In addition to the personal challenges of migration, a part of today's global educational field, migrant teachers' professional identity becomes a subject of reflection and transformation when they encounter the Swedish educational system and the use of digital technologies in a digitised society. In Sweden, there is a government-mandated programme called "Utländska Lärares Vidareutbildning" [Further Education for Foreign Teachers], which started in 2007. The programme is still running in 2019 and offers additional training for people who have a foreign teaching degree and wish to become eligible to teach in Sweden. In this programme, an individual study plan for 1-2 years is designed, including educational science, as well as education about the Swedish school's organisation, values, laws, and knowledge about grading, among other things. During their education, migrant teachers receive help to identify competencies they already have, those they need to modify for their new teacher role, as well as methods that might not carry over into their new role. Lastly, migrant teachers have a placement period, where they can put theoretical knowledge into practical use.

\section{Theoretical framework}

\section{Transformative learning}

In order to understand migrant teachers' experiences with the use of digital technologies, the concept of transformative learning was applied. Life today is a time of constant change and transformation, which make learning a lifelong process. According to Illeris (2014b, p. 40), transformative learning is defined like this: "The concept of transformative learning comprises all learning, which implies changes in the identity of the learner."

Transformative learning, as a concept, was launched by Mezirow (1978), while he was studying women's liberation processes in courses, during which changes in their self-perceptions were seen. For Mezirow, transformative learning involved qualitative changes in the learner's perspectives of meaning (how a person understands him- or herself), mainly cognitive, or frames of reference (meaning perspectives). Most central in transformative learning is critical thinking. Critical thinking and change fall in line with Taylor's argument (2012) that a necessity for intercultural 
understanding is the ability to think critically about one's own beliefs and then change.

Mezirow's definition has been criticised for being too narrow, which made Illeris (2014a; 2014b; 2014c) widen the concept. According to Illeris (2017), there are two basic processes of learning: the integration of external interaction and the internal psychological elaboration. The latter involves the content (what is learned) and the learning incentive (motivation, emotion, volition). All learning is situated; specific situations are experienced and interpreted by the learner (Illeris, 2014b; 2017).

There is a distinction between learning as:

- addition (cumulative, a pattern already is established)

- assimilative (new things are added to what is already known)

- change (accommodative)

There are different types of accommodation: the ordinary - when someone understands something in a new way by accepting what is different, and the transformative - when the learner changes his meaning, perspectives, or ways of behaviour. Transformative learning includes cognitive, emotional, and social dimensions. For Illeris (2014a; 2014b; 2014c; 2017), the target area of transformative learning is the identity, covering cognitive, emotional, and social dimensions.

There are three layers in Illeris' (2014c) model of identity. First, we have an inner core, the core identity, which is quite constant and specific for the individual. Secondly, we have the personality layer, which is the main target for transformative learning. This layer changes with new experiences and consists of an individual's values, understanding, behaviour, habits of communication, patterns of collaboration, et cetera. Lastly, we have the preference layer, a more surface-based layer that relates to additional learning as what a person prefers, routines, automatic reactions, and is not targeted for transformative learning. During life, the identity is created, developed, and changed. In addition to the three layers, Illeris (2014b) addresses the person as a whole, with part-identities known as attitudes (national-cultural identity and religious-political identity), and practice (work-, family- and every day/interest identity). Migrant teachers often find themselves in a huge transition that relates to these part-identities: changing country, language, and sometimes, experiencing unfamiliar teaching and learning. Identifying competence development that meets migrant teachers' needs becomes important. For Illeris (2014a), competence is more than qualification; it reinforces the learner's capability to function in new situations, closely related to one's identity and how one functions in society.

Knowing that competence helps a learner to function in a new environment, there are some elements to integrate into migrant teachers' 
further development. According to Taylor (2009), there are some core elements that guide a transformative practice: individual experience, critical reflection, dialogue/discussion, awareness of context, and authentic relationships. Altogether, transformative learning demands a learnercentred approach. For Illeris (2014b; 2017), a practice or problemoriented teaching and learning is a must. The competence development requires a) engagement, b) practice/problem, and c) reflection. However, the transformation can be offensive, regressive, or defensive when it is too demanding, and the learner can feel uncertain about education. The result can be withdrawal or regression if the learner lacks the strength or qualifications to deal with change. Another consequence can be to resign and accept things (Illeris, 2014b; 2017).

\section{The aim of the study and research questions}

Both technology development and migration are part of the global educational field. With these comes, diversity in the use of digital technologies and pedagogy. In order to understand migrant teachers' experiences of the use of digital technologies in Swedish teacher education, we have to investigate the estimated use of technologies in their former teacher education in relation to the Swedish one, as well as their view of teaching and learning. There is a lack of studies examining migrant teachers' experience with the use of digital technologies (in Swedish teacher education). This study aims to understand migrant teachers' experience when digital technologies are used in Swedish teacher education, in relation to Illeris' redefined transformative learning (Illeris, 2014b).

Research questions:

- Which estimated use of digital technologies did migrant teachers experience in teacher education programmes?

- What view do migrant teachers have about teaching and learning?

- What learning, in relation to Illeris' redefined theory of transformative learning, was identified when digital technologies were used?

\section{Methods}

\section{Research design}

A convergent mixed methods design was used (Creswell \& Plano Clark, 2011). Both quantitative and qualitative data were collected through a web survey, individual interviews, focus groups, and reflective texts written by the participants. The data results and analysis were mixed and converged to gain a more nuanced view of the respondents' experiences. The purpose of a converged mixed methods design is to use both qualitative and quantitative results, analyse them each separately and then mix them. 


\section{Population}

The web survey targeted all actively enrolled migrant teacher students participating in a government-mandated programme: "Further Education for Foreign Teachers". An overall view of the population can be seen in Appendix A. A call for participation in the qualitative data collection was included in the web survey and the email to all enrolled migrant teachers. The migrant teachers' former teacher education was conducted in 57 countries/regions. Four Swedish universities participated in this study. Due to confidentiality, the participating universities were named: University A, University B, University C, and University D. Migrant teachers are a heterogeneous group. In Appendix B, their age, years of former teacher education at the university level and specialisations are displayed.

\section{Ethics}

The Swedish Research Council (Hermerén, 2017) states that the main concepts of ethical concern in research are professional secrecy, anonymising or de-identifying respondents, and confidentiality, which were considered in this study as follows. Information was given to the migrant teachers about the study's purpose, representation, and the voluntary nature of participation. Furthermore, migrant teachers were informed that participation would not affect their grades and that they could withdraw from the study at any time.

\section{Data collection}

To provide material that complemented each other, a mix of four data collection methods - a web survey, individual interviews, focus group interviews, and participants' reflective texts - were used. Contact was made to the National Director for the project and the administration at each university, and information about the present study was given. Through the Universities' administrations, the respondents' emails were sent to the author.

\section{Quantitative data}

The respondents received information about the web survey in several ways (via management systems, email, seminars, and lectures) and it was sent via an online system to the entire population of 465 migrant teachers, and of those, 228 (49\%) answered. The survey contained an information page and four sections: a) demography; b) teaching philosophy; c) ways of thinking and practising in Swedish education that could be experienced as unfamiliar; and d) digital competence. The respondents could answer the web survey with any digital device, and they could stop whenever they 
wanted and continue at any time. In this article, the focus is on section a, $\mathrm{b}$ and $\mathrm{d}$ of the survey.

\section{Qualitative data}

All data collections covered the following themes: ways of thinking and practising, digital competence, and teaching philosophy. At the end of the survey, the migrant teachers had the opportunity to permit the author to contact them for an interview. Semi-structured interviews were conducted, including nine individual interviews and five focus group interviews with a total of 34 individuals. Both the focus group and the individual interviews were held at the participants' universities in rooms that were familiar to them, lasted between 40 to 70 minutes and were digitally audio recorded by the interviewer. The migrant teachers were instructed that there were no right or wrong answers and that it was essential to reveal their own experiences. As an introduction to the interviews, the respondents were shown the thematic areas that would be discussed during the interviews. The focus group method was chosen to capture experiences, enabling migrant teachers to share and compare with each other. This interaction reveals data not captured in individual interviews. On the other hand, the individual interviews provided more in-depth insights since the participants were able to express themselves without the influence of others (Cousin, 2009). Additionally, reflective texts and the open-ended answers from the web-survey were collected. Fifteen migrant teachers sent in 30 reflective texts, stemming from the course: "To be a teacher in Sweden" (22.5 credits). As a course assignment at University A, migrant teachers were asked to reflect over teaching and learning in Sweden compared to their former teacher education and work. The texts were voluntarily sent through an online system or sent to the author by email.

\section{Data analysis}

The survey contributed to background data about the migrant teachers, see Appendix A, and Appendix B. The other quantitative data from the web survey were analysed using SPSS version 24, and Excel 2013 showing numbers and percentages. In addition, a descriptive analysis was conducted. Each of the interviews was transcribed verbatim in Swedish. The qualitative data was transferred into MAXQDA version 12, and Pro analytics 2018, a qualitative data analysis software, for further processing and content analysis. The qualitative data were read several times to obtain an overview and understanding of the material. The segments were coded into categories and quotations were chosen based on their representativeness. The mixed analysis quantified some of the qualitative data. In addition, 
it made the quantitative data more transparent by displaying qualitative quotations connected to them.

\section{Results}

\section{Parts in the results}

This study described migrant teachers estimated the use of digital technologies in teacher education programmes and, in addition, their view of teaching and learning. Furthermore, migrant teachers' experiences when digital technologies were used, were identified and discussed in relation to Illeris' theory of redefined transformative learning. The results were divided into three parts: (A) Estimated use of digital technologies; (B) View of teaching and learning and (C) Digital technologies, learning and identity. First, a non-response analysis will be presented.

\section{Non-response analysis}

The response rate of the online survey was 49\%, see Appendix A. The participants who answered the survey were $88 \%$ female and $12 \%$, male. They covered the entire spectra of migrant teachers concerning age, subjects, and specialisation. Furthermore, all were active students with the possibility to respond to the survey, which makes the natural non-response (not being able to answer because of serious illness, travels) a non-issue. Other aspects could have an impact on the non-response: The fact that the survey was in Swedish, not the participants' first language; it was a lengthy survey and; there was a possible lack of interest in the subject of digital competence. It could also be that for some participants, the effort to use the devices and answer the survey was daunting. Although the response rate had a risk of bias due to language difficulties and the length of the digital survey, the convergent research design covered a broad spectrum of perspectives from migrant teaching students.

\section{(A) Estimated use of digital technologies}

To understand the use of digital technologies in Swedish teacher education, it was of interest to investigate if it was used by teacher educators and placement supervisors at their former teacher education programmes as well. Migrant teachers estimated what percentage of their teacher educators and placement supervisors, in Sweden and their former countries, combined content, digital technologies and teaching strategies. The estimated use in Sweden was measured after at least one semester, up until the end of their further development studies. An overview can be seen in Figure. 


\section{THE USE OF DIGITAL TECHNOLOGIES}

\begin{tabular}{|c|c|c|c|c|}
\hline $\begin{array}{rr} & 140 \\
& 120 \\
& 100 \\
& 80 \\
& 80 \\
& 60 \\
\text { " } \quad & 40 \\
& 20\end{array}$ & 1 & & & \\
\hline 0 & $25 \%$ or less & $26 \%-50 \%$ & $51 \%-75 \%$ & $76 \%-100 \%$ \\
\hline $\begin{array}{c}\text { Former country - Teacher } \\
\text { education }\end{array}$ & 122 & 45 & 23 & 13 \\
\hline $\begin{array}{c}\text { - } \\
\text {-Sweden - Teacher } \\
\text { education }\end{array}$ & 16 & 37 & 70 & 82 \\
\hline $\begin{array}{c}\text { Former country - } \\
\text { Placement supervisors }\end{array}$ & 126 & 40 & 21 & 12 \\
\hline $\begin{array}{c}\text {-Sweden - Placement } \\
\text { supervisors }\end{array}$ & 27 & 51 & 70 & 50 \\
\hline
\end{tabular}

Figure. Results of the use of digital technologies

Note. This table shows how migrant teachers estimate the use of digital technologies in teacher education in Sweden and former teacher education, as well as the placement supervisors during their placement period in both countries.

When looking at the 76-100th percentile, see Figure, the results show that the use of digital technology was estimated higher in Sweden, both in teacher education ( $n=82$ ) and among the placement supervisors $(n=50)$, in comparison with their former teacher education $(n=13)$, as well as among their placement supervisors $(n=12)$. However, there were migrant teachers who thought that digital technologies were used more often in their former education. The result is not to be read that the use of digital technologies is more prevalent in Sweden. It was not possible to make this comparison since, to have accurate results, the study should be done in each country at the same time. However, the results give information regarding if migrant teachers, who attend Swedish teacher education programmes, were educated in digital technologies in their former countries.

In the mixed method analysis of using digital technologies in teacher education, three qualitative categories of use were found and counted, a) more use in Swedish teacher education $(n=172)$, b) the same use in both countries ( $n=56)$, and c) more use at former teacher education ( $n=12$ ), altogether $N=240$ qualitatively coded segments. 
Table. A mixed methods table that shows the number and quotations of the use of digital technologies in teacher education in relation to former teacher education

\begin{tabular}{|l|l|l|}
\hline \multicolumn{1}{|c|}{ Category } & \multicolumn{1}{|c|}{$\begin{array}{c}\boldsymbol{N}=\mathbf{2 4 0} \\
\text { qualitative coded } \\
\text { segments }\end{array}$} & \multicolumn{1}{c|}{ Quotation } \\
\hline $\begin{array}{l}\text { a) more use in } \\
\text { Swedish teacher } \\
\text { education }\end{array}$ & $(n=172)$ & $\begin{array}{l}\text { 'The teaching is different [in Sweden], there } \\
\text { are a lot of digital technologies in use that } \\
\text { I never had as a teacher-student [former } \\
\text { country]. The other thing is the way you } \\
\text { participate as a teacher-student during } \\
\text { the lessons; I was not used to this.' }\end{array}$ \\
\hline $\begin{array}{l}\text { b) the same use } \\
\text { in both countries }\end{array}$ & $(n=56)$ & 'No, there is no difference.' \\
\hline $\begin{array}{l}\text { c) more use at } \\
\text { former teacher } \\
\text { education }\end{array}$ & $(n=12)$ & $\begin{array}{l}\text { 'I believe that the spectrum of courses is } \\
\text { broad [former country]. Parallel with courses } \\
\text { in the subject is didactical courses how } \\
\text { to teach, didactical knowledge and tools. } \\
\text { Later on, you try them out in reality during } \\
\text { the practice. You must show your theoretical } \\
\text { knowledge in practice, adapting your } \\
\text { lessons.' }\end{array}$ \\
\hline
\end{tabular}

In category a) More use of digital technologies in Swedish teacher education ( $n=172$ qualitative coded segments), migrant teachers were not only referring to the amount of digital technology in use as being something unfamiliar but also how and why it was used in teaching and learning. The accessibility and possibility to use digital technologies was lacking in the former country due to money issues, war, or restrictions by the government to use some of the technologies, or that the former education was conducted a long time ago. Other reasons were lack of interest or incitement to use digital technology or that more traditional methods for teaching and learning were preferred.

In category b) The same use $(n=56)$, migrant teachers found the use of digital technologies in Swedish teacher education familiar and the teaching and learning that comes with it. Digital technologies used for information, administration, and presentations were common in their former education as well.

In category c) More use at the former teacher education $(n=12)$, migrant teachers expressed that digital technologies were used more often and were well-integrated in all subjects in their former teacher education. The use of digital tools and apps (online collaborative learning, social media, smartboards, programs included in the subject books, programming, and working with different projects using e-learning) were taught and integrated in practice. Migrant teachers studied the subject content parallel 
with courses in digital technologies. Moreover, they practised what was learned during their placement period.

\section{(B) View of teaching and learning}

A task and a challenge for teacher education, when providing further development for migrant teachers, is the diversity within the views of teaching and learning. Teachers' philosophies have bearing on which teaching approaches are chosen, hence how digital technologies are used and experienced in teacher education. Findings in this study show this diversity in teaching philosophy, the view of the role as a teacher, the students, how learning occurs and finally, the relationship between education and society. The web survey included 23 statements about teaching philosophy, answered by $n=213$ to $n=219$ migrant teachers. For more detailed findings, see Appendix C.

A common discussion is whether teaching should be teacher- or studentcentred. A teacher-directed education was agreed with by $n=116$, but $n=27$ of migrant teachers disagreed. Altogether, most of the migrant teachers saw themselves as mainly both a subject expert $(n=136)$ and mentor $(n=177)$, and moreover, preferred to work in a team $(n=142)$. However, there are migrant teachers that rejected a mentoring $(n=14)$ and an intermediary ( $n=47)$ teacher role and preferred to work alone $(n=21)$. However, to have a more caring and cherished teacher role was agreed with by $n=140$, while only $n=18$ disagreed. In Sweden, the emphasis is on student-centred teaching, both within teacher education and in schools.

Findings connected to migrant teachers' views of the role as a student show that a majority view students as responsible and independent ( $n=123$ ), while $n=23$ disagreed. Seeing students as passive and needing to be controlled so that learning can occur was more evenly distributed $n=60$ migrant teachers agreed, $n=55$ neither agreed nor disagreed, and $n=98$ disagreed. Despite this, the majority also viewed students as responsible and independent, and considered training students' social skills ( $n=176)$ and independence $(n=178)$ a task for the teacher.

The statements about learning show a diverse picture. The statement that students learn the most when schools emphasise hard work, respect and discipline were agreed with by $n=95$ migrant teachers, $n=61$ neither agreed nor disagreed, and $n=60$ disagreed. In addition, a majority saw the importance of student motivation related to learning ( $n=205)$ and creating an encouraging atmosphere which promotes the students' development $(n=206$ ). How students learn was a divider. Social learning, the idea that students learn most when they work together, was agreed with by a majority $(n=164)$. Autonomous, self-directed learning was not 
appreciated by all, and even though $n=147$ migrant teachers agreed that students should be active, decide what and how they shall learn something, $n=16$ disagreed with this idea. A majority agreed with the statement that teaching shall build on students' earlier experiences ( $n=174$ ), be aligned with the students' understanding $(n=209)$, and adapt individually to each student $(n=169)$. However, there were still those who disagreed. The findings show that some migrant teachers disagreed to learning built on earlier experiences ( $n=12)$, align with understandings $(n=3)$, and individually adapted ( $n=17$ ). Process or product focus on learning divided the teachers. The focus shall be on the teaching process and not the end product was agreed with by $n=133$, however, $n=57$ neither agreed nor disagreed, and $n=26$ disagreed. In Sweden, both active autonomous and social learning is common. Furthermore, building on earlier experiences and understanding and emphasising the process is considered important.

Some of the statements were directed towards the role of education in society. In Sweden, this is important in ordinances and curricula. Most migrant teachers agreed with a close working relationship between school, education and society ( $n=179$ ), also that teaching should relate to life outside school $(n=190)$. Sweden is a digitalised society, and only $n=7$ migrant teachers disagreed that information technology must be integrated into teaching. A more diverse picture showed $n=123$ agreeing and $n=42$ disagreeing with the statement: Education shall be the same in all schools and not vary between different teachers.

\section{(C) Digital technologies, learning and identity}

This study aims to understand migrant teachers' learning when digital technologies are used in Swedish teacher education, in relation to Illeris' redefined transformative learning (2014b). The target area for transformative learning is the identity (cognitive, emotional, and social). It is important to remember that migrant teachers are not a homogenous group; there is a span between unfamiliar to familiar experiences, with learning that is individually situated and interpreted. In this second part, the three layers of identity were used for categorising the migrant teachers' experiences: a) The core identity; b) The personality layer, and c) The preference layer. Regressive transformative learning will also be discussed.

\section{The core identity}

Migrant teachers, having come to Sweden for many different reasons such as war, work, or relationships, are in a huge transition, changing cultures and language. "When I migrated to Sweden, I was in limbo for a year. I did not know who I was; I got problems with my identity." Expressing this 
touches the core centre of the identity, wherewith a person has the sense of being an individual. On their journey towards finding themselves as individuals and their role as teachers in Sweden, they expressed that this society has shared perspectives, certain values and principles that are taken for granted but can appear contradictory to those of their former country. It can be very different from having a work identity as a teacher in Sweden, seen as more of a supervisor while coming from a country where the teacher is viewed as a strong authoritative figure that people look up to. "I was like a mayor in my former country." The analysis also presented that some migrant teachers used digital technologies to process and understand their identities in the new Swedish context compared to their former country. Digital technologies and its influence on identity, gender issues, et cetera were considered unfamiliar and an eye-opener.

\section{The personality layer}

Expressions of unfamiliarity in the personality layer, related to values, behaviour, and how to collaborate, were found. As for the core identity, some migrant teachers used digital technology as a tool to gain knowledge and compare concepts to understand the foundation of teaching and learning in Sweden in relation to themselves as teachers. "I searched the Internet to compare the concept of fundamental values within educational systems [in different countries]." However, it was not only the technology that was unfamiliar; the challenge of shifting pedagogical perspectives was a big issue. "It was scary being so autonomous from the beginning." For some migrant teachers, the ordinary accommodation, understanding and accepting new ways, was not enough. Hence, a transformative accommodation, in which the migrant teacher changes both the meaning perspectives and ways of behaviour, was expressed. There was a conflict between earlier strategies for learning and how one perceived oneself.

It was problematic for me to conform... It took me about a year to get used to and use this way of learning [self-directed, autonomous]. I was very stressed out. You have the former system of doing things within you.

Furthermore, within the new learning context, new patterns of collaboration followed. Digital communication and socialisation, as part of their studies, were experienced as unfamiliar, especially in the teacher educator-migrant teacher relationship. "I never socialised with teachers online [former country]." According to migrant teachers, digital technologies can make contact better, the feeling that the teacher educator sees them - for example, with giving answers and feedback more easily. There is a risk, though that the use of online technologies minimises the time with the teacher educator. Online tools can decrease the gap, but only if the teacher educator is present and engaged in the online environment. 
However, teaching about digital technologies and how they are used in social interaction [in Sweden] is lacking, even though it is something new. "Interesting insights for me were the learning connected to social aspects."

Digital technologies were mostly recognised by migrant teacher students as an aid in their studies. The idea that they could experience help even when they were not on-site at the education programme, the accessibility to lectures, peer support, and writing and communicating with others was something important. "It [digital technologies] helped me to finish my studies." Furthermore, using online technology was helpful due to the large variety in their private lives. "For me, as a mother, digital technologies made it so much easier to study... I did not have to leave my children at home." For some migrant teachers, learning to communicate online was more like learning as change, in both the ordinary accommodation and transformative learning, as they were not used to being exposed to sharing their thoughts and texts in this way. In these cases, the external and internal elaboration was more of a challenge. Thus, migrant teachers express a lack of education in the use of digital technologies for teaching and learning.

In teacher education [Sweden] we use digital technologies almost every lesson, presentations et cetera. We do not get it [how to use it in teaching and learning] from the teacher education though; it is mostly that you search for yourself. We got a little tip about digital technologies in the didactics study, however.

\section{The preference layer}

The preference layer of the identity relates to what an individual prefers, routines, etc., and learning as addition or assimilation is common. Here, migrant teachers convey usage of digital technologies for information and administration that do not demand deeper processing or identity change from the user. "The teacher educators use learning management systems [or other online tools] a lot for the information and a place where we can find and send in papers." Using digital technologies, for example, LMS, information websites, and email was not experienced as problematic, but rather the opposite - it made studying easier - even though the administrative digitalisation within Swedish teacher education and how information is distributed was experienced as unfamiliar. Information about how to use online tools, however, was sometimes insufficient. "It was a new system; if you can use it, then it is a good thing. I had some problems, in the beginning, to find information or to guide myself within the system." 


\section{Regressive transformative learning}

Not all of the migrant teachers experienced the use of digital technologies as something helpful and useful; some expressed negativity or scepticism regarding its use. This can happen when transformative learning goes against what a migrant teacher wants or considers important. "I think it is very bad to use of digital technologies." Digital technology was considered negative for learning and a waste of time. Furthermore, regressive transformative learning was evident when migrant teachers identified themselves as digitally illiterate, and at the same time, lacked sufficient training from Swedish teacher education. Moreover, autonomous, student-centred teaching, was rejected by some migrant teachers. "What kind of learning is that [about social learning]?" It was stressful for migrant teachers when both digital technologies and the pedagogy were unfamiliar.

\section{Discussion}

In the global educational field, migrated teachers are becoming an asset to education in their new home countries. This study aimed to understand migrant teachers' experiences when digital technologies are used in Swedish teacher education. To understand this, there was a need to investigate if migrants were educated about using digital technologies in their former teacher education, moreover their view of teaching and learning. A mixed method was used, combining different collection methods, results and analysis. This enhanced the validity and reliability since the qualitative and quantitative results supported each other. Limitations of the study connected to the web survey were present, such as the response frequency of $49 \%$, the lengthiness of the web survey, and that it was in Swedish.

Currently, migrant teachers come to Sweden, a highly digitised society (Davidsson \& Thoresson, 2017; OECD, 2018), for further education. The practice and attitudes within their work identity as professional teachers are in transformation. Earlier studies displayed that teaching students (Swedish in general) requested more education about how to teach with digital technologies (Enochsson, 2009; Demoskop, 2016) since being digitally competent is a growing demand in a digitalised society (Bautista \& Ortega-Ruiz, 2015) and teachers want useable competencies. This is confirmed in the present study as well, even though digital technologies are heavily used in Swedish teacher education. Migrant teachers are not a homogenous group; the analyses showed a significant variation in the learning experienced when digital technologies were used. The use in administration, information and communication was well met. However, the connection within learning: the why what, and how they learn in 
a digital environment - the pedagogical use of digital technologies - was found to be lacking.

Migrant teachers who were familiar with digital technologies in their former countries expressed the pedagogical use as student-centred, social learning, describing a genuine competence development that influenced how they taught and behaved like a teacher, reaching the personality layer of the identity. This is supported in Taylor's (2009), Illeris' (2014b) and Mezirow's (1978) description of transformative practice and was something these migrant teachers experienced in their former teacher education. Teaching and learning strategies used in Swedish teacher education, in general, are autonomous, student-active education, and social learning, among other methods, but not always when digital technologies are used. Migrant teachers who felt comfortable in the Swedish educational context could just add to what they already knew since the teaching and learning was already familiar as a work identity. Consequently, learning as addition or assimilation (Illeris, 2014b) was more common, often reaching the preference layer and sometimes the personality layer.

Migrant teachers who expressed a more extensive use of digital technologies in the Swedish teacher education programme than in the former country meant both in the amount and how and why it is used. The methods were unfamiliar to them, suggesting learning as change, and new teaching and learning strategies took up to one year to learn and use, with or without digital technologies. The learning process that facilitated self-directed learning and emphasised motivation was not familiar. This mirrored if digital technologies were important in their former society and education. Some called themselves digitally illiterate.

Interestingly, some used digital technologies for identity processing, cognitive, emotional, and social transformation. They expressed that they met many new challenges which conflicted with their former identity and practice as teachers (both in teacher education and in schools). When competence development is planned with identity and transformative learning in mind, it targets the personality layer, changing values, behaviour, and patterns of collaboration. However, when helping migrant teachers to personalise and individualise the teaching and learning, ways of teaching and learning must be assimilated since it is not something all teachers agree to use.

Closely related to learning as change is how competence is viewed, as a prerequisite for qualification, or giving one the capacity to meet the unknown. The latter is a critical component for both transformative learning and the use of digital technologies, which are each a target for continuous development into the unknown. Learning of a transformative nature, cognitively, emotionally, and socially is vital if digital technologies 
will be used in teaching and learning. It is important to make transparent which opportunities migrant teachers have to reflect over transformative challenges in their professional development using digital technologies. If proper learning does not occur, regression and resignation can be the outcome instead.

Further studies concerning migrant teachers, transformative learning and identity, would make the integration process and how to design further development in education more transparent. Implications of the analysis highlight that a more diversified further development of digital technologies connected to teaching and learning must be developed. Furthermore, digital technologies can be used in teacher education at a deeper level, as an aid to identify and problematize the migrant teacher's identity and role. Lastly, migrant teachers express that it takes a lot of time to adjust to a new teaching and learning environment.

\section{Conclusions}

Coming to a new society and experiencing new learning contexts can be a considerable transition, demanding authentic competence development and transformative learning that targets the personality layer. Migrant teachers have mixed backgrounds, a diversity which concerns digital competence as well as their views about teaching and learning. It is beneficial to investigate the current digital competence of the individual migrant teacher with emphasis on what is required in the situated educational context, in addition to understanding and analysing which teaching and learning methods suit the current group - always with the migrant teachers' view of teaching and learning in mind. Lastly, it is important to plan for transformative learning, giving migrant teachers the opportunity to critically reflect over and interlink their teaching professions from the past, present, and future. This can be accomplished by using a learner-oriented, problem-based approach with critical reflection in dialogue with others, including cognitive, emotional, and social aspects. This takes time and effort; however, it will enhance digital competence. Furthermore, it is essential to understand that migrant teacher are an asset to Swedish teacher education, with pedagogical competence from different parts of the world. The exchange and learning experience is beneficial for all. 


\section{References}

Bautista, A., \& Ortega-Ruiz, R. (2015). Teacher professional development: International perspectives and approaches. Psychology, Society and Education, 7(3), 343-355.

Creswell, J. W., \& Plano Clark, V. L. (2011). Designing and conducting mixed methods research. (2.ed.). Los Angeles: SAGE Publications. doi:978-1-4129-7517-9.

Cousin, G. (2009). Researching learning in higher education: An introduction to contemporary methods and approaches. Routledge.

Davidsson, P., \& Thoresson, A. (2017). Svenskarna och internet 2017: Undersökning om svenskarnas internetvanor. [The Swedes and Internet 2017: An investigation about Swedes' Internet habits.] IIS, Internetstiftelsen i Sverige. Retrieved from https://www. iis.se/docs/Svenskarna_och_internet_2017.pdf.

Demoskop. (2016). Report. Lärarutbildning och digitalisering - en undersökning bland Sveriges lärarstudenter. [Teacher education and digitalisation: An investigation among teacher studentsin Sweden.] Stockholm: Demoskop. Retrieved from https://www. berattarministeriet.se/undersokning/.

The Digitalisation Commission. (2014). En digital agenda $i$ människans tjänst: en ljusnande framtid kan bli vår (SOU 2014:13) [A digital agenda in human service: A bright future can be ours.] Stockholm: Näringsdepartementet. [Ministry of Enterprise and Innovation]. Retrieved from https://www.regeringen.se/rattsliga-dokument/ statens-offentliga-utredningar/2014/03/sou-201413/.

The Digitalisation Commission. (2017). National Digitalisation Strategy for the school system. Ministry of Education and Research. Retrieved from https://www.regeringen. se/4a 9d9a/contentassets/00b3d9118b0144f6bb95302f3e08d11c/nationelldigitaliseringsstrategi-for-skolvasendet.pdf.

Enochsson, A-B. (2009). ICT in Initial Teacher Training - Sweden country report. OECD. Hermerén, G. (2017). Good research practice. Stockholm: The Swedish Research Council.

Illeris, K. (2017). Learning, development and education: From learning theory to education and practice. Routledge.

Illeris, K. (2014a). Transformative learning and identity. Journal of Transformative Education, 12(2), 148-163. doi:10.1177/1541344614548423.

Illeris, K. (2014b). Transformative Learning and Identity. London: Routledge. https://doi. org/10.4324/9780203795286.

Illeris, K. (2014c). Transformative learning re-defined: As changes in elements of the identity. International Journal of Lifelong Education, 33(5), 573-586. doi:10.1080/02 601370.2014 .917128 .

Käck, A., Männikkö Barbutiu, S., \& Fors, U. (2018). Unfamiliar ways of thinking and practising in teacher education: experiences by migrant teachers. In M. Sablic, A. Skugor, \& I. Durdevic Babic (Eds.), Proceedings of the $42^{\text {nd }}$ ATEE Annual Conference 2017 in Dubrovnik, Croatia: Changing Perspectives and Approaches in Contemporary Teaching (pp. 219-235). Brussels, Belgium: Association for Teacher Education in Europe (ATEE). https://atee.education/knowledge-center/publications/.

Mezirow, J. (1978). Perspective transformation. Adult education, 28(2), 100-110. doi: $10.1177 / 074171367802800202$.

Ministry of Education and Research. (2014). Högskoleförordningen 2014:1096, Kapitel 2. [The Higher Education Ordinance 2014:1096, Annex 2]. Retrieved from 
https://www.uhr.se/en/start/laws-and-regulations/Laws-and-regulations/The-HigherEducation-Ordinance/Annex-2/.

Ministry of Enterprise and Innovation. (2011). IT i människans tjänst: en digital agenda för Sverige. [IT in the service of the humans: A digital agenda for Sweden]. Stockholm: Näringsdepartementet.

National Agency for Education. Lgr 11. (2017). Läroplan för grundskolan, förskoleklassen och fritidshemmet 2011: Reviderad 2017. [Curriculum for the compulsory school, preschool class and the recreation centre]. Stockholm: Skolverket.

National Agency for Education. Lgy 11. (2017). Läroplan för gymnasieskolan: Lgy 11. [Curriculum for the upper secondary school]. Stockholm: Skolverket.

National Agency for Education. Lpfö 98. (2016). Läroplan för förskolan: Lpfö 98 [Curriculum for pree school]. Stockholm: Skolverket.

OECD. (2018). OECD reviews of digital transformation: Going digital in Sweden. Paris: OECD Publishing. doi:10.1787/9789264302259-en.

Taylor, E. W. (2009). Fostering transformative learning. In J. Mezirow, Taylor, E.W. \& Associates: Transformative learning in practice: insights from community, workplace, and higher education. San Francisco, Calif: Jossey-Bass.

Taylor, E. W., \& Cranton, P. (2012). Handbook of transformative learning: theory, research, and practice. Retrieved from https://ebookcentral-proquest-com.ezp.sub.su.se. 
Appendix A. Summary of Data Collection Activities

\begin{tabular}{|l|l|}
\hline \multicolumn{1}{|c|}{ Data collection } & \multicolumn{1}{|c|}{ Former teacher education in: } \\
\hline Survey & Algeria, Argentina, Azerbaijan, Bangladesh, \\
$N=228$ (out of 465) 49\%: & Belarus, Belgium, Bosnia and Herzegovina, \\
$12 \%$ male and $88 \%$ female & Brazil, Bulgaria, Canada, Central America, \\
University A: $n=180$ of $380(47 \%)$ & Chile, China, Costa Rica, Cuba, Egypt, \\
University B: $n=18$ of $30(60 \%)$ & Ethiopia, Finland, Georgia, Germany, \\
University C: $n=9$ of $15(60 \%)$ & Greece, Hungary, India, Iraq, Iran, Japan, \\
University D: $n=21$ of $40(52.5 \%)$ & Jordan, Kenya, Kosovo, Kurdistan, Latvia, \\
& Lebanon, Lithuania, Mongolia, Netherlands, \\
& Nicaragua, Pakistan, Palestine, Philippines, \\
Poland, Romania, Russia, Serbia, Spain, & South Africa, Syria, Taiwan, Thailand, \\
& Turkey, Ukraine, USA, Uzbekistan, \\
Yugoslavia, Zambia
\end{tabular}

Notes. Value $N=$ Total number of respondents, value $n=$ number of respondents in a case. 
Appendix B. Background data of migrant teachers

\begin{tabular}{|c|c|}
\hline Migrant teachers & $\underline{\text { Data collection }}$ \\
\hline Years of age & $\begin{array}{l}\text { Quantitative: } \\
\text { - 25-31 years, } n=36 \\
\text { 32-38 years, } n=80 \\
\text { - } 39-45 \text { years, } n=56 \\
\text { - more than } 45 \text { years, } n=50 \\
\text { Qualitative: the same span }\end{array}$ \\
\hline $\begin{array}{l}\text { Years of former teacher } \\
\text { education }\end{array}$ & $\begin{array}{l}\text { Quantitative: } \\
\text { - } 2 \text { years, } n=36 \\
\text { - 3-4 years, } n=96 \\
\text { - more than } 5 \text { years, } n=79 \\
\text { - graduate students, } n=8 \\
\text { Qualitative: the same span }\end{array}$ \\
\hline $\begin{array}{l}\text { Specialisations } \\
\text { (The migrant teachers } \\
\text { could tick more } \\
\text { than one box for } \\
\text { specialisation in the } \\
\text { web-survey) }\end{array}$ & 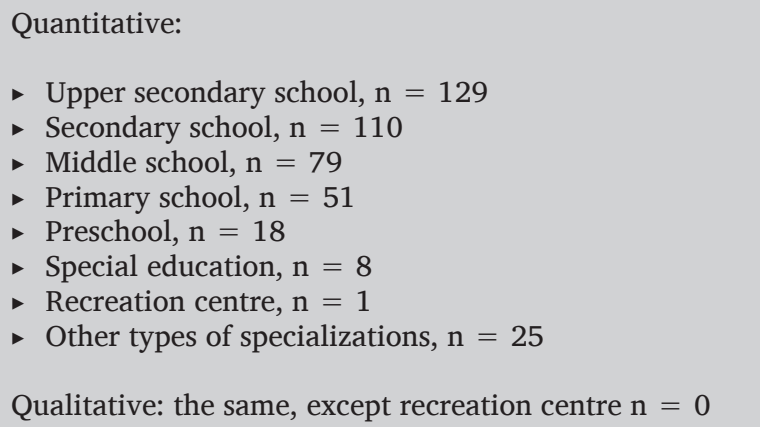 \\
\hline Subject areas & $\begin{array}{l}\text { Quantitative data: social science, nature science, } \\
\text { language, mathematics, art, music, special education, } \\
\text { preschool, gymnastics and sports and health, } \\
\text { recreation centres, country-specific } \\
\\
\text { Qualitative data: social science, nature science, special } \\
\text { education, gymnastics, sports and health, language } \\
\text { (English, French, Russian, some Mother's tongue), } \\
\text { literature, mathematics, art, music, computers and } \\
\text { technology, psychology, country-specific }\end{array}$ \\
\hline
\end{tabular}


Appendix C. Teaching philosophy - numbers and \% from the web survey

\begin{tabular}{|c|c|c|c|c|}
\hline Questions in the survey & $\boldsymbol{N}=$ & $\begin{array}{l}\text { Strongly } \\
\text { disagree/ } \\
\text { Disagree }\end{array}$ & $\begin{array}{l}\text { Neither } \\
\text { agree nor } \\
\text { disagree }\end{array}$ & $\begin{array}{l}\text { Agree/ } \\
\text { Strongly } \\
\text { Agree }\end{array}$ \\
\hline $\begin{array}{l}\text { 1. Students shall be active, decide what } \\
\text { and how they shall learn something }\end{array}$ & $N=219$ & $\begin{array}{l}n=16 \\
8 \%\end{array}$ & $\begin{array}{l}n=56 \\
26 \%\end{array}$ & $\begin{array}{l}n=147 \\
67 \%\end{array}$ \\
\hline $\begin{array}{l}\text { 2. Education shall be directed by } \\
\text { the teacher }\end{array}$ & $N=217$ & $\begin{array}{l}n=27 \\
12 \%\end{array}$ & $\begin{array}{l}n=74 \\
34 \%\end{array}$ & $\begin{array}{l}n=116 \\
54 \%\end{array}$ \\
\hline $\begin{array}{l}\text { 3. I see myself as an intermediary of } \\
\text { facts and information }\end{array}$ & $N=213$ & $\begin{array}{l}n=47 \\
22 \%\end{array}$ & $\begin{array}{l}n=46 \\
22 \%\end{array}$ & $\begin{array}{l}n=120 \\
56 \%\end{array}$ \\
\hline $\begin{array}{l}\text { 4. Students learn the most when } \\
\text { schools emphasize hard work, respect } \\
\text { and discipline }\end{array}$ & $N=216$ & $\begin{array}{l}n=60 \\
28 \%\end{array}$ & $\begin{array}{l}n=61 \\
28 \%\end{array}$ & $\begin{array}{l}n=95 \\
44 \%\end{array}$ \\
\hline $\begin{array}{l}\text { 5. I am mainly a mentor who helps } \\
\text { the students }\end{array}$ & $N=218$ & $\begin{array}{l}n=14 \\
6 \%\end{array}$ & $\begin{array}{l}n=27 \\
12 \%\end{array}$ & $\begin{array}{l}n=177 \\
81 \%\end{array}$ \\
\hline $\begin{array}{l}\text { 6. Students are passive and must be } \\
\text { controlled so that learning can occur }\end{array}$ & $N=213$ & $\begin{array}{l}n=98 \\
46 \%\end{array}$ & $\begin{array}{l}n=55 \\
26 \%\end{array}$ & $\begin{array}{l}n=60 \\
28 \%\end{array}$ \\
\hline $\begin{array}{l}\text { 7. Teaching shall be adapted } \\
\text { individually to each student }\end{array}$ & $N=218$ & $\begin{array}{l}n=17 \\
8 \%\end{array}$ & $\begin{array}{l}n=32 \\
15 \%\end{array}$ & $\begin{array}{l}n=169 \\
78 \%\end{array}$ \\
\hline $\begin{array}{l}\text { 8. I am mainly a subject expert } \\
\text { who shall give the students subject } \\
\text { competence }\end{array}$ & $N=216$ & $\begin{array}{l}n=27 \\
12 \%\end{array}$ & $\begin{array}{l}n=53 \\
25 \%\end{array}$ & $\begin{array}{l}n=136 \\
63 \%\end{array}$ \\
\hline $\begin{array}{l}\text { 9. The students need to be motivated } \\
\text { to want to learn something }\end{array}$ & $N=218$ & $\begin{array}{l}n=5 \\
2 \%\end{array}$ & $\begin{array}{l}n=8 \\
4 \%\end{array}$ & $\begin{array}{l}n=205 \\
94 \%\end{array}$ \\
\hline $\begin{array}{l}\text { 10. I must train the students' social } \\
\text { skills }\end{array}$ & $N=218$ & $\begin{array}{l}n=12 \\
6 \%\end{array}$ & $\begin{array}{l}n=30 \\
14 \%\end{array}$ & $\begin{array}{l}n=176 \\
81 \%\end{array}$ \\
\hline $\begin{array}{l}11 . \text { The individual school and society } \\
\text { outside shall have a close working } \\
\text { relationship }\end{array}$ & $N=216$ & $\begin{array}{l}n=11 \\
5 \%\end{array}$ & $\begin{array}{l}n=26 \\
12 \%\end{array}$ & $\begin{array}{l}n=179 \\
83 \%\end{array}$ \\
\hline $\begin{array}{l}\text { 12. Education shall be the same in all } \\
\text { schools and not vary between different } \\
\text { teachers }\end{array}$ & $N=216$ & $\begin{array}{l}n=42 \\
19 \%\end{array}$ & $\begin{array}{l}n=51 \\
24 \%\end{array}$ & $\begin{array}{l}n=123 \\
57 \%\end{array}$ \\
\hline $\begin{array}{l}\text { 13. Students are responsible and } \\
\text { independent }\end{array}$ & $N=218$ & $\begin{array}{l}n=23 \\
11 \%\end{array}$ & $\begin{array}{l}n=72 \\
33 \%\end{array}$ & $\begin{array}{l}n=123 \\
57 \%\end{array}$ \\
\hline $\begin{array}{l}\text { 14. I shall train the students to be } \\
\text { independent individuals }\end{array}$ & $N=216$ & $\begin{array}{l}n=14 \\
6 \%\end{array}$ & $\begin{array}{l}n=24 \\
11 \%\end{array}$ & $\begin{array}{l}n=178 \\
82 \%\end{array}$ \\
\hline $\begin{array}{l}\text { 15. Teaching shall relate to life outside } \\
\text { of school }\end{array}$ & $N=217$ & $\begin{array}{l}n=7 \\
3 \%\end{array}$ & $\begin{array}{l}n=20 \\
9 \%\end{array}$ & $\begin{array}{l}n=190 \\
88 \%\end{array}$ \\
\hline $\begin{array}{l}\text { 16. Students learn most when they } \\
\text { work together }\end{array}$ & $N=217$ & $\begin{array}{l}n=12 \\
5 \%\end{array}$ & $\begin{array}{l}n=41 \\
19 \%\end{array}$ & $\begin{array}{l}n=164 \\
75 \%\end{array}$ \\
\hline $\begin{array}{l}\text { 17. Teaching shall build on students' } \\
\text { earlier experiences }\end{array}$ & $N=215$ & $\begin{array}{l}n=12 \\
6 \%\end{array}$ & $\begin{array}{l}n=29 \\
13 \%\end{array}$ & $\begin{array}{l}n=174 \\
81 \%\end{array}$ \\
\hline
\end{tabular}




\begin{tabular}{|l|l|l|l|l|}
\hline \multicolumn{1}{|c|}{ Questions in the survey } & $\boldsymbol{N}=$ & $\begin{array}{l}\text { Strongly } \\
\text { disagree/ } \\
\text { Disagree }\end{array}$ & $\begin{array}{l}\text { Neither } \\
\text { agree nor } \\
\text { disagree }\end{array}$ & $\begin{array}{l}\text { Agree/ } \\
\text { Strongly } \\
\text { Agree }\end{array}$ \\
\hline $\begin{array}{l}\text { 18. I must create an encouraging } \\
\text { atmosphere which promotes } \\
\text { the students' development }\end{array}$ & $N=217$ & $\begin{array}{l}n=2 \\
1 \%\end{array}$ & $\begin{array}{l}n=9 \\
4 \%\end{array}$ & $\begin{array}{l}n=206 \\
95 \%\end{array}$ \\
\hline $\begin{array}{l}\text { 19. Teaching shall be aligned with } \\
\text { the students' understanding }\end{array}$ & $N=218$ & $\begin{array}{l}n=3 \\
1 \%\end{array}$ & $\begin{array}{l}n=6 \\
3 \%\end{array}$ & $\begin{array}{l}n=209 \\
96 \%\end{array}$ \\
\hline $\begin{array}{l}\text { 20. I shall take care of and cherish } \\
\text { the students }\end{array}$ & $N=216$ & $\begin{array}{l}n=18 \\
8 \%\end{array}$ & $\begin{array}{l}n=58 \\
27 \%\end{array}$ & $\begin{array}{l}n=140 \\
65 \%\end{array}$ \\
\hline $\begin{array}{l}\text { 21. The focus shall be on the teaching } \\
\text { process and not the end product }\end{array}$ & $N=216$ & $\begin{array}{l}n=26 \\
12 \%\end{array}$ & $\begin{array}{l}n=57 \\
26 \%\end{array}$ & $\begin{array}{l}n=133 \\
62 \%\end{array}$ \\
\hline $\begin{array}{l}\text { 22. Information technology must be } \\
\text { integrated in teaching }\end{array}$ & $N=218$ & $\begin{array}{l}n=7 \\
3 \%\end{array}$ & $\begin{array}{l}n=33 \\
15 \%\end{array}$ & $\begin{array}{l}n=178 \\
82 \%\end{array}$ \\
\hline $\begin{array}{l}\text { 23. I would rather work in a team than } \\
\text { alone }\end{array}$ & $N=218$ & $\begin{array}{l}n=21 \\
10 \%\end{array}$ & $\begin{array}{l}n=55 \\
25 \%\end{array}$ & $\begin{array}{l}n=142 \\
65 \%\end{array}$ \\
\hline
\end{tabular}

